\title{
Knowledge to Ecological Preferences in a Tropical Epiphytic Algae to Use with Eutrophication Indicators
}

\author{
Yimmy Montoya-Moreno, Néstor Aguirre-Ramírez
}

GeoLimna group, Engineering Faculty, Antioquia University, Medellin, Colombia.

Email: yimmymontoya3@hotmail.com

Received July $31^{\text {st }}, 2013$; revised September $2^{\text {nd }}, 2013$; accepted October $5^{\text {th }}, 2013$

Copyright (C 2013 Yimmy Montoya-Moreno, Néstor Aguirre-Ramírez. This is an open access article distributed under the Creative Commons Attribution License, which permits unrestricted use, distribution, and reproduction in any medium, provided the original work is properly cited.

\begin{abstract}
In Ayapel floodplain periphyton associated to macrophyte roots on the basis of material was collected in fourteen sampling sites in nine moments of compilation. From the analysis of the samples were recorded 550 algal species, of which $56 \%$ were diatoms. Furthermore it was valued relative abundances of taxa and the average physicochemical variables to identify the optimal values and tolerance ranges of species. In the case of nitrates optimal value was below $2 \mathrm{mg} / \mathrm{L}$ for all algae except for Actinella sp. and Euastrum sinuosum which optimal values were close to zero with low variability. Regarding all species the algal nitrite concentration showed optimum values below $2 \mathrm{mg} / \mathrm{L}$ except Encyonema minutum and E. sinuosum whose optimum were 0.4 and $0.5 \mathrm{mg} / \mathrm{L}$ respectively. About nitrogen as ammonia was repeated the above situation, i.e. optimum values below $2 \mathrm{mg} / \mathrm{L}$ except for E. minutum and E. sinuosum. Respect to phosphorus the species with optimum greater than $0.6 \mathrm{mg} / \mathrm{L}$ are the diatoms, in contrast, the lowest values were optimal for $E$. sinuosum and Actinella sp. From the viewpoint of bioindication high abundance of Synedra goulardii indicates high transparency, Ulnaria ulna and Planothidium lanceolatum indicate lower concentration of dissolved oxygen and water temperature between $29^{\circ} \mathrm{C}-30^{\circ} \mathrm{C}$, Actinella aff. robusta, E. minutum, Cylindrospermopsis raciborski, Lyngbya cf. limnetica, Eunotia naegueli, Navicula cryptocephala, Diadesmis confervaceae, Frustulia rhomboides and Aulacoseira granulata. Indicating low electrical conductivity $(<100 \mu \mathrm{S} / \mathrm{cm})$, Synedra goulardii indicating neutral waters, Actinella eunotioides and Euastrum sinuosum indicate low nitrate concentration $(<0.2 \mathrm{mg} / \mathrm{L})$, Eunotia minor indicating midrange nitrite concentration $(0.2-0.5 \mathrm{mg} / \mathrm{L})$, Ulnaria ulna, Planothidium lanceolatum indicating low ammoniacal nitrogen concentration $(<0.2 \mathrm{mg} / \mathrm{L})$ and Actinella eunotioides indicating low soluble reactive phosphorus concentration $(<0.2 \mathrm{mg} / \mathrm{L})$.
\end{abstract}

Keywords: Algae; Epiphyton; Bioindicator; Tropical Environment

\section{Introduction}

The abundance of species among other factors is determined by their rate of growth, and depends on the environmental conditions. The success of species in reproductive terms will be in relation to optimal values of a set of environmental variables for that species and their range of tolerance [1].

To determine the species responses to the set of variables specific to their environment, we can explore its distribution through direct multivariate analysis, such as the redundancy analysis and canonical correspondence analysis [2]. In this way information is obtained from species responses to multivariate environmental gradients. To identify the ecological preferences of the species with respect to an environmental variable in particular its op- timum based on its position in this gradient, as well as their tolerance to variations can be estimated. It is important to define accurately the autoecological characteristics of the species for use in bioindication [1].

In Colombia barely begins to explore this research line, which starts from the recent work of Bogotá wetlands [3] who concluded that the assessment of ecosystems through the species of diatoms is the most successful to achieve a discrimination in the limnological state of these bodies of water, in contrast to the saprobien indexes and the diatom generic indexes. This researcher developed a diatoms biotic index to assess the state of Bogota wetlands (IDHB), established that wetlands covered by the study have wide range of conditions from lightly polluted to severely polluted and it showed also that these conditions were sus- 
ceptible to changes in time. Correlations between the IDHB and the physical variables and chemical pollution presented values of high significance.

Water eutrophication has become a worldwide environmental problem in recent years, and understanding the mechanisms of water eutrophication will help for prevention and remediation of water eutrophication [4]. Algae is one the most important component studies in eutrophication evaluation, so it is necessary to know its potential indicator in relationship with water conditions. Algae in special diatoms are frequently used as indicators of eutrophication in temperate systems [5], but little is known about their application to impacted South American tropical systems. The idea of this work is to build a record of environmental conditions in which the algae are in an optimum level in tropical natural conditions and in the future, be able to have a large picture of the environmental requirements of the microalgae and identify which algae are the best indicators of environmental conditions in a tropical flood plain.

\section{Material and Methods}

\subsection{Study Area}

In Ayapel flood plain system, between May 2006 and January 2009 nine sampling campaigns were carried out, which include three hydrological cycles of the system at different times of the flood pulse. Information has been published on environmental and physicochemical variables [6], taxonomical report [7,8], social appropriation of science [9-11] and dynamic of periphytic algae assemblage associated with macrophytes prevailing in each of the 14 stations of monitoring [12,13].

\subsection{Calculated Index}

From the distribution matrix to epiphytic algae in different substrates, identified the species that presented more than $1 \%$ relative abundance and there were presented in $30 \%$ of the evaluated samples. To estimates of optimal values of environmental variables for each species $(u k)$ using weighted averages were calculated an average of the values of the environmental variable for all of the sites where the species was found weighted with their relative abundance, using the following formula [1,14-16].

$$
u k=\sum_{n} y i k \cdot x i / \sum_{n} y i k
$$

$y i k$ : abundance of $k$ species on the $i$ site.

$x i$ : value of the environmental variable in the $i$ site.

The tolerance of the species or weighted standard deviation $(t k)$ was calculated according to [15].

$$
t k=\sum_{i=1}^{n} y i k \cdot(x i-u k)^{2} / \sum_{i=1}^{n} y i k
$$

\section{Results}

The maximum and minimum values for each studied physical chemistry variable (Table 1) were determined. A high variability due to the effect of the flood pulse and spatial gradients in Ayapel flood plain system were identified.

555 morphospecies were identified. Diatoms and desmidias were the dominant groups in terms of species richness and abundance. In the first group there were 56 genera and 252 species, of which 13 genera and 103 species are new taxa to Colombia. They correspond to the $50.8 \%$ total diatoms identified in this country. On the second group of desmidias, 107 species in 17 genera were found. Several new species to science were found too, which are in the process of description to be published.

Table 2 presents the list of species selected from among the 555 registered in samples, as the most important ecological system.

Figures 1(a)-(m) show the optimal and tolerance of selected species. The species are organized from lowest to highest value of the evaluated parameter, are represented in order to reveal differences in the optimal values of these.

Depending on the level of the flood pulse most of the algae present optimal values under $3 \mathrm{~m}$ of the water column and some diatoms (Eunotia flexuosa, Eunotia naegueli, Actinella aff. robusta, Diadesmis confervaceae, Planothidium lanceolatum, Ulnaria ulna), Oedogonium

\begin{tabular}{|c|c|c|c|}
\hline Variable & $\begin{array}{l}\text { Minimum } \\
\text { value }\end{array}$ & $\begin{array}{l}\text { Maximum } \\
\text { value }\end{array}$ & Range \\
\hline Total depth (m) & 0.41 & 6.7 & 6.29 \\
\hline Secchi transparency $(\mathrm{m})$ & 0.08 & 1.7 & 1.62 \\
\hline Water temperature $\left({ }^{\circ} \mathrm{C}\right)$ & 28.2 & 35.6 & 7.4 \\
\hline Dissolved oxygen (mg/L) & 0.4 & 10.6 & 10.2 \\
\hline $\mathrm{pH}$ (pH units) & 5.3 & 7.73 & 2.43 \\
\hline Electrical conductivity $(\mu \mathrm{S} / \mathrm{cm})$ & 12.1 & 261 & 248.9 \\
\hline Total suspended solids (mg/L) & 1 & 76 & 75 \\
\hline Dissolved solids (mg/L) & 23 & 538 & 515 \\
\hline Nitrate $(\mathrm{mg} / \mathrm{L})$ & 0 & 5 & 5 \\
\hline Nitrite $(\mathrm{mg} / \mathrm{L})$ & 0 & 2.1 & 2.1 \\
\hline Ammoniacal nitrogen (mg/L) & 0 & 0.42 & 0.42 \\
\hline Soluble reactive phosphorus $(\mathrm{mg} / \mathrm{L})$ & 0.03 & 2.8 & 2.77 \\
\hline Sulfates $(\mathrm{mg} / \mathrm{L})$ & 0.121 & 38 & 37.879 \\
\hline Saturation oxygen $(\%)$ & 4.73 & 143 & 138.27 \\
\hline
\end{tabular}

Table 1. Environmental variables range. 
Table 2. List of species selected as the most important ecological system.

\begin{tabular}{|c|c|}
\hline Acronym & Species \\
\hline & Cyanobacteria \\
\hline CYRA & $\begin{array}{c}\text { Cylindrospermopsis raciborski (Woloszynska) } \\
\text { Seenayya \& Subba Raj }\end{array}$ \\
\hline LYSP & Lyngbya cf. limnetica Lemmermann \\
\hline \multirow[t]{2}{*}{ OSSP } & Oscillatoria $\mathrm{sp}$ \\
\hline & Streptophyta \\
\hline EUSI & Euastrum sinuosum Lenormand ex W. Archer \\
\hline \multirow{3}{*}{ OESP } & Chlorophyta \\
\hline & Oedogonium sp \\
\hline & Bacilariophyta \\
\hline ACLA & Actinella aff. robusta Hustedt \\
\hline ACSP & Actinella eunotioides Hustedt \\
\hline AUGR & Aulacoseira granulata (Ehrenberg) Simonsen \\
\hline AGAN & $\begin{array}{l}\text { Aulacoseira granulata var angustissisima } \\
\text { (O. Müller) Simonsen }\end{array}$ \\
\hline DICO & Diadesmis confervaceae Kützing \\
\hline ENJE & Encyonema jemtlandicum Krammer \\
\hline ENMI & Encyonema minutum (Hilse in Rabernhorst) D. G. Mann \\
\hline EUFL & Eunotia flexuosa (Brebisson) Kützing \\
\hline EUMI & Eunotia minor (Kützing) Grunow in Van Heurck \\
\hline EUNA & Eunotia naegueli Migula \\
\hline FRCA & Fragilaria capucina Desmazieres \\
\hline FRFA & Synedra rumpens var. familiaris (Kützing) Hustedt \\
\hline FRKR & Frustulia rhomboides (Ehrenberg) De Toni \\
\hline GOPA & Gomphonema parvulum (Kützing) Kützing \\
\hline NACR & Navicula cryptocephala Kützing \\
\hline PLLA & $\begin{array}{c}\text { Planothidium lanceolatum (Brébisson ex Kützing) } \\
\text { Lange-Bertalot }\end{array}$ \\
\hline SYGO & Synedra goulardii Brébisson \\
\hline ULUL & Ulnaria ulna (Nitzsch) P. Compère \\
\hline
\end{tabular}

sp. and Lymbia sp. recorded optimal values at greater depths (Figure 1(a)).

The algae are adapted to low transparency levels (Figure 1(b)) since all have optimal below $1 \mathrm{~m}$ of transparency. According to the water temperature, the optimal values are above $29^{\circ} \mathrm{C}$ and in the case of the cyanobateria Oscillatoria and Lymbia and diatom Actinella eunotioides reach optimal value round to $32^{\circ} \mathrm{C}$ (Figure 1(c)).

All algae have optimal values less than $6 \mathrm{mg} \cdot \mathrm{L}^{-1}$ of dissolved oxygen (Figure 1 (d)) and subsaturate oxygen percentages, with values lower than $40 \%$ for most of the algae, between $40 \%$ and $60 \%$ for Synedra rumpens var. familiaris, Navicula cryptocephala, Actinella eunotioides, Aulacoseira granulata var. angustissisima and $80 \%$ in the case of Synedra goulardii (Figure 1(e)).

Electrical conductivity algae are grouped into two levels according to their optimal value (Figure 1(f)), most have optimal below $100 \mu \mathrm{S} / \mathrm{cm}$ and Euastrum sinuosum, S. goulardii, Planothidium lanceolatum and Ulnaria ulna exhibit optimal values above $100 \mu \mathrm{S} / \mathrm{cm}$. Total suspended solids (Figure 1(g)) show all algae have optimal less than $20 \mathrm{mg} \cdot \mathrm{L}^{-1}$. The optimal values for total dissolved solids are lower than the $100 \mathrm{mg} \cdot \mathrm{L}^{-1}$ (Figure 1(h)).

With respect to the $\mathrm{pH}$ (Figure 1(i)), with the exception of $P$. lanceolatum and Oscillatoria sp. which feature optimal values less than $\mathrm{pH} 6$, the rest of the algae present optimal circumneutral ( $\mathrm{pH}$ between 6 and 7). Although $U$. ulna presents a wide tolerance to variations in $\mathrm{pH}$.

About wih nutrients concentrations, in the case of nitrate its optimal value was below the $2 \mathrm{mg} \cdot \mathrm{L}^{-1}$ for all algae, although it must be emphasized that Actinella aff. robusta and E. sinuosum present optimal values close to zero and low variability (Figure 1(j)). With respect to the nitrite concentration all algae have optimum values below $2 \mathrm{mg} \cdot \mathrm{L}^{-1}$ (Figure 1(k)) except Encyonema minutum and E. sinuosum which have optimal values of 0.4 and $0.5 \mathrm{mg} \cdot \mathrm{L}^{-1}$ respectively. In the case of ammoniacal nitrogen, repeats it the previous situation, i.e., optimal values below $2 \mathrm{mg} \cdot \mathrm{L}^{-1}$ except $E$. minutum and E. sinuosum (Figure 1(l)). In the case of the SRP species that were on the right side of the gradient are diatoms which present an optimal value exceeding $0.6 \mathrm{mg} \cdot \mathrm{L}^{-1}$, in contrast, with lower optimal values Actinella aff. robusta and E. sinuosum (Figure 1(m)).

Finally, the sulphate optimum concentration for algae was around $2 \mathrm{mg} \cdot \mathrm{L}^{-1}$ and only some diatoms most (Fragilaria capucina, Synedra rumpens var. familiaris, Eunotia flexuosa) and the cyanobateria Lyngbia reach optimal near the $4 \mathrm{mg} \cdot \mathrm{L}^{-1}$ (Figure 1(n)).

Differential responses among the desmidias and diatoms were not found when selected at the level group, because differences the optimal values correspond to the nature of each species. Algae that showed conditions restricted for distribution can be considered candidates to be used as bioindicator of the ecological quality of water (Table 3).

\section{Discussion}

The ecological preferences of algae periphytic studied, in relation to the water level, predominantly optimal values were closed to the surface of the water, which may be 

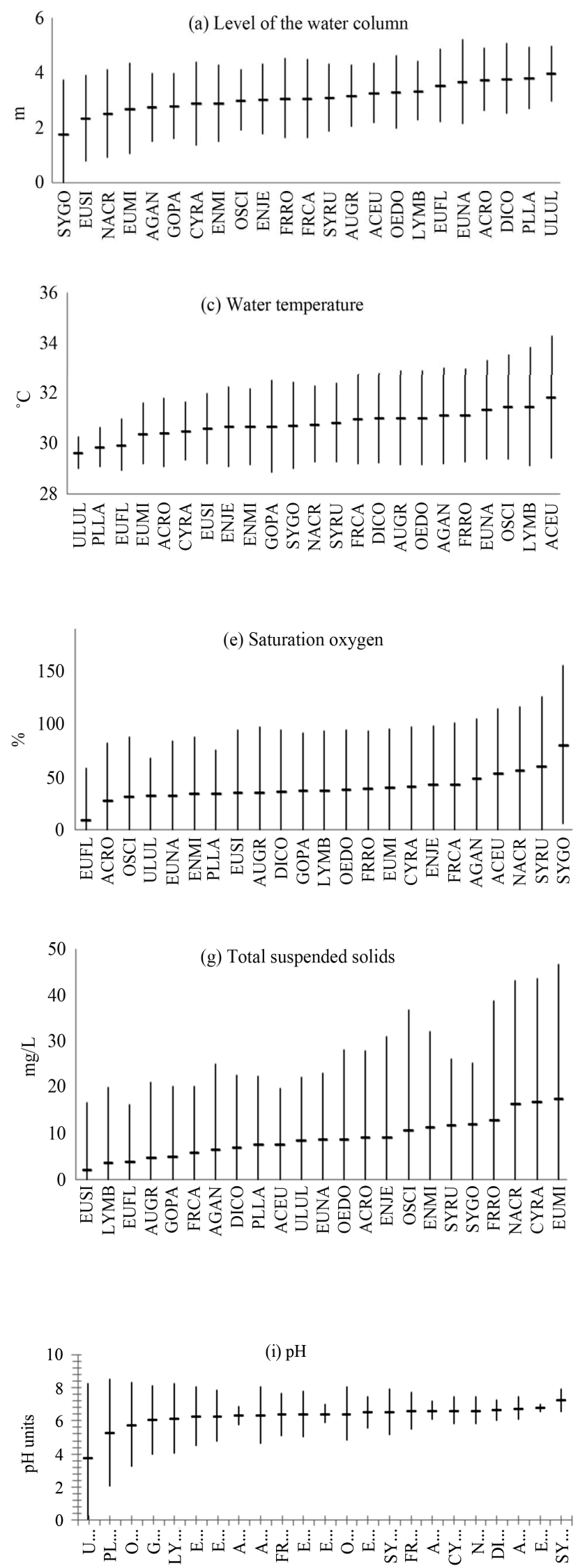
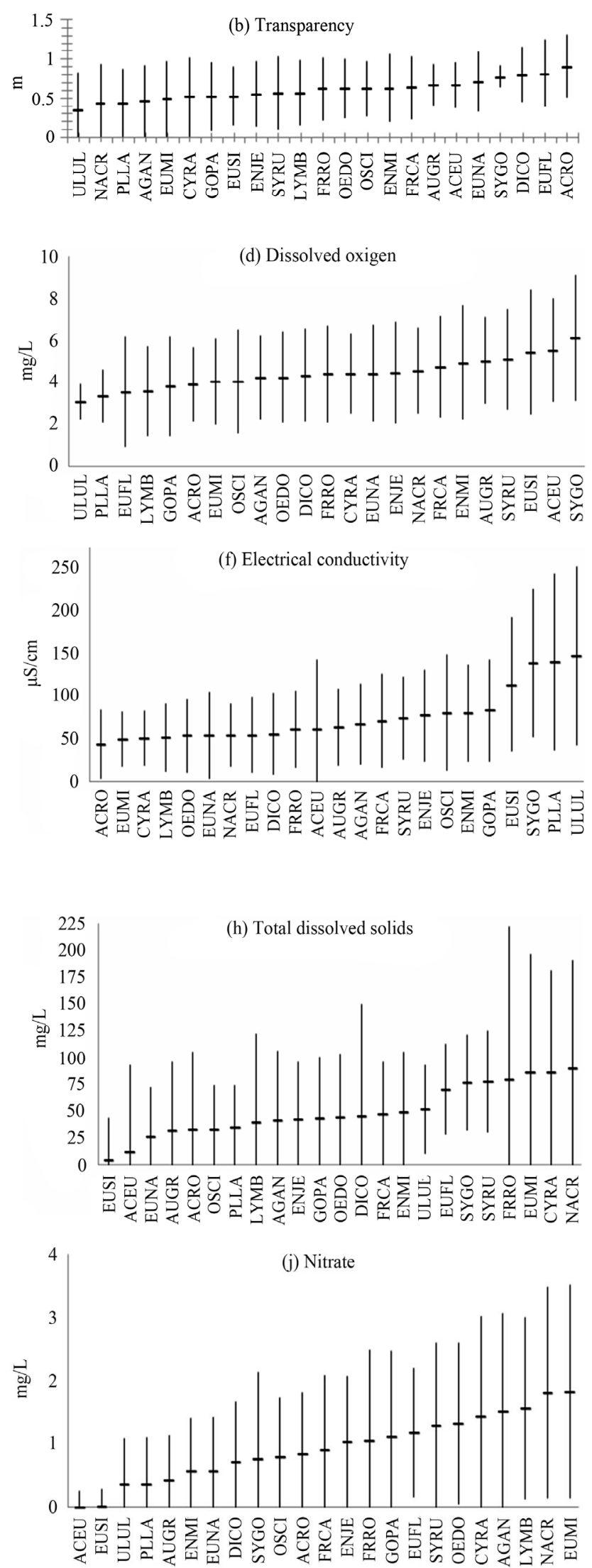

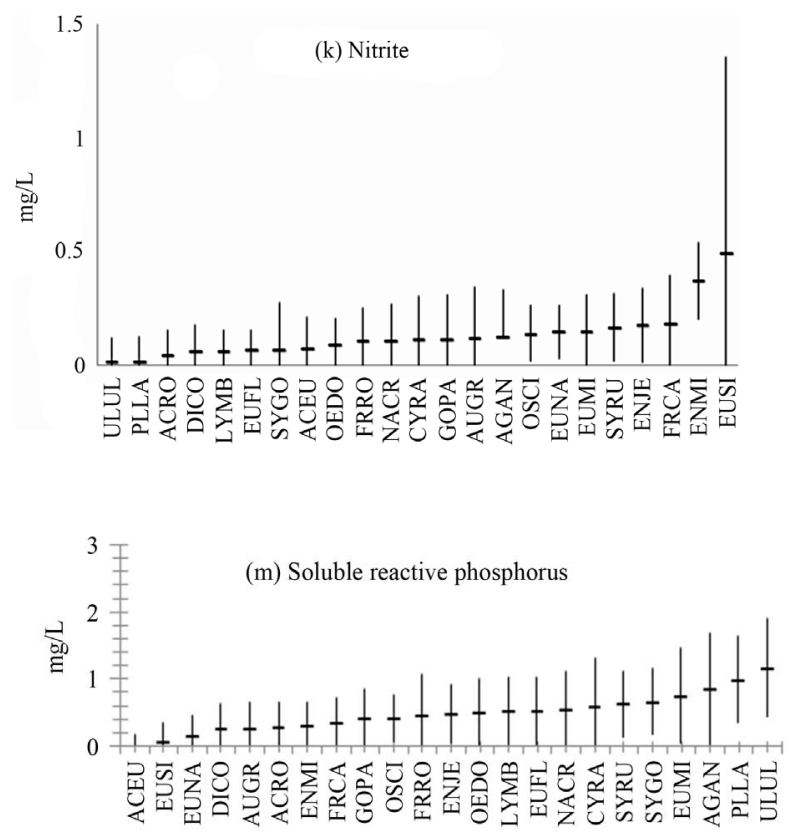
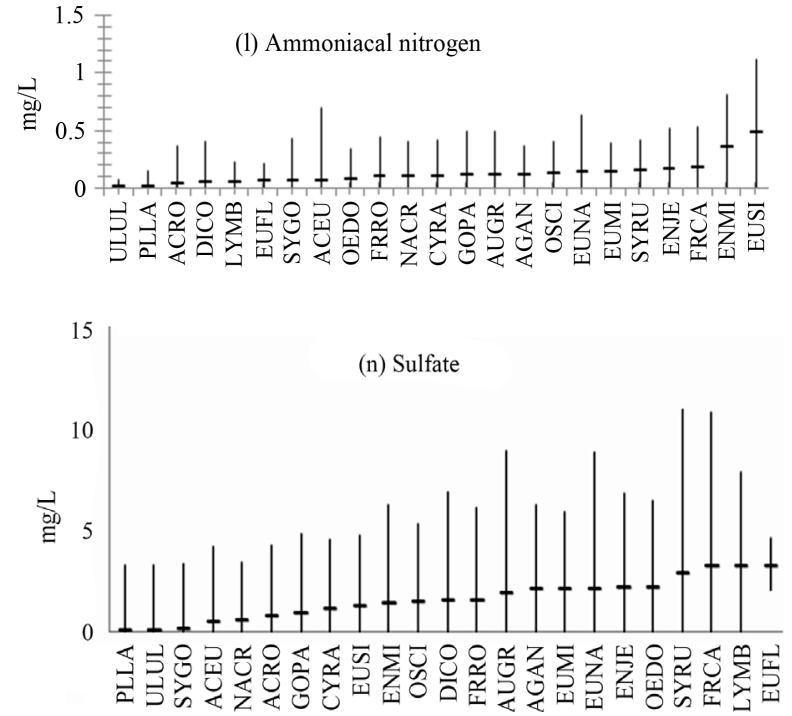

Figure 1. Physicochemical optimal and tolerance of selectionated species.

Table 3. Species indicators of water conditions in Ayapel flood plains system.

\begin{tabular}{|c|c|}
\hline Water feature & Taxones \\
\hline High transparency $(0.7-0.9 \mathrm{~m})$ & Synedra goulardii. \\
\hline Low water temperature $\left(29^{\circ} \mathrm{C}-30^{\circ} \mathrm{C}\right)$ & Ulnaria ulna, Planothidium lanceolatum. \\
\hline Low dissolved oxygen $(2.2-4)$ & Ulnaria ulna, Planothidium lanceolatum. \\
\hline Low electrical conductivity $(<100 \mu \mathrm{S} / \mathrm{cm})$ & $\begin{array}{c}\text { Actinella aff. robusta, Encyonema minutum, Cylindrospermopsis raciborski, } \\
\text { Lyngbya } \mathrm{cf} \text {. limnetica, Oedogonium } \mathrm{sp}, \text { Eunotia naegueli, Navicula cryptocephala, } \\
\text { Diadesmis confervaceae, Frustulia rhomboides, Aulacoseira granulata. }\end{array}$ \\
\hline Low total suspended solids $(<25 \mathrm{mg} / \mathrm{L})$ & $\begin{array}{c}\text { Euastrum sinuosum, Lyngbya cf. limnetica, Eunotia flexuosa, Aulacoseira granulata, } \\
\text { Gomphonema parvulum, Fragilaria capucina, Aulacoseira granulata var angustissisima, } \\
\text { Diadesmis confervaceae, Planothidium lanceolatum, Actinella aff. robusta, Ulnaria ulna, } \\
\text { Eunotia naegueli, Synedra rumpens var familiaris, Synedra goulardii. }\end{array}$ \\
\hline Low total dissolved solids $(<50 \mathrm{mg} / \mathrm{L})$ & Euastrum sinuosum. \\
\hline Midrange total dissolved solids (30 - $120 \mathrm{mg} / \mathrm{L})$ & Eunotia flexuosa, Synedra goulardii, Synedra rumpens var familiaris. \\
\hline Slightly acid water $(\mathrm{pH}=6)$ & $\begin{array}{c}\text { Actinella eunotioides, Euastrum sinuosum, Eunotia naegueli, Actinella aff. robusta, } \\
\text { Cylindrospermopsis raciborski, Navicula cryptocephala, Diadesmis confervaceae, } \\
\text { Aulacoseira granulata, Eunotia flexuosa. }\end{array}$ \\
\hline Neutral waters $(\mathrm{pH}=7)$ & Synedra goulardii. \\
\hline Low nitrate concentration $(<0.2 \mathrm{mg} / \mathrm{L})$ & Actinella eunotioides, Euastrum sinuosum. \\
\hline Low nitrite concentration $(<0.2 \mathrm{mg} / \mathrm{L})$ & $\begin{array}{c}\text { Ulnaria ulna, Planothidium lanceolatum, Actinella aff. robusta, Diadesmis } \\
\text { confervaceae, Lyngbya } \text { cf. limnetica, Eunotia flexuosa, Synedra goulardii, } \\
\text { Actinella eunotioides, Oedogonium sp. }\end{array}$ \\
\hline Midrange nitrite concentration $(0.2-0.5 \mathrm{mg} / \mathrm{L})$ & Eunotia minor. \\
\hline Low ammoniacal nitrogen concentration $(<0.2 \mathrm{mg} / \mathrm{L})$ & Ulnaria ulna, Planothidium lanceolatum. \\
\hline $\begin{array}{l}\text { Low soluble reactive phosphorus concentration }(<0.2 \\
\qquad \mathrm{mg} / \mathrm{L})\end{array}$ & Actinella eunotioides. \\
\hline Low sulfate concentration $(<12 \mathrm{mg} / \mathrm{L})$ & $\begin{array}{c}\text { Cylindrospermopsis raciborski, Lyngbya } \mathrm{cf} \text {. limnetica, Oscillatoria } \mathrm{sp}, \text { Euastrum } \\
\text { sinuosum, Oedogonium sp, Actinella aff. robusta, Actinella eunotioides, Aulacoseira } \\
\text { granulata, Aulacoseira granulata var angustissisima, Diadesmis confervaceae, } \\
\text { Encyonema jemtlandicum, Encyonema minutum, Eunotia flexuosa, Eunotia minor, } \\
\text { Eunotia naegueli, Fragilaria capucina, Synedra rumpens var familiaris, } \\
\text { Frustulia rhomboides, Gomphonema parvulum, Navicula cryptocephala, } \\
\text { Planothidium lanceolatum, Synedra goulardii, Ulnaria ulna. }\end{array}$ \\
\hline
\end{tabular}


related with the fact of these live organisms in the upper part of the photic zone [17] found in this system that the phytoplankton assemblage responded to the temporal variation of flood pulse and during the dry season, the water level reduction, promoted the generation of spatial gradients, this response was mainly reflected by the temporary changes in the biovolume because in terms of composition the most important taxa are temporarily stable.

Two morphologically related species were found (Synedra goulardii and Ulnaria ulna) which present optimal values opposed to transparency, the level of water, the concentration of oxygen and saturation, so that it can be inferred that taxonomic errors can lead to erroneous environmental interpretations. In addition this specific variability is according to the genera and the evaluated variable differential.

[18] reported to Synedra goulardii as inhabitant of oligotrophic environments and indicator of low transparency, what was also evident in this research. Investigators recorded in an Ecuadorian lagoon of flood plain as dominant species in some sampling stations (located in a river that passes near several villages), in which reached up to the $70 \%$ of taxa abundance [19].

Ulnaria ulna is considered mesosaprobic [20] and estuarine [18], although this condition does not arise in this study, since evidenced an optimal pattern stenothermic, which can be favored by high temperatures in the area throughout the year.

Planothidium lanceolatum presented the lower $\mathrm{pH}$ optimum value, in the literature this species is recorded as of wide variability from the point of view of the $\mathrm{pH}$ (acidophilus, neutrophil, alkalophilic), trophic index (oligotrophic, mesotrophic, and eutrophic) and is found in high concentrations of dissolved oxygen [18]. This condition does not arise in Ayapel system, oxygen concentrations are low, undersaturated and these species presented an optimal $3.3 \mathrm{mg} / \mathrm{L}$ with less than $40 \%$ oxygen saturation, allowing further ecological information on this species. [18] presented to U. ulna and P. lanceolatum as inhabitants of systems with high ionic charges.

The genus Actinella has tropical distribution and in South America has been carried out the largest number of descriptions of the same, with 12 species [21], most of which are found in acidic waters [22]. A few environmental information is known about this genera, so it is highlighted to if two species are found (Actinella aff. robusta and Actinella eunotioides), which are optimal at $\mathrm{pH}$ slightly acid, high levels of the column of water, high transparency, warm temperature and subsaturate dissolved oxygen between $30 \%$ and $60 \%$, conductivities of less than $60 \mu \mathrm{S} / \mathrm{cm}$, low concentrations of SST and STD, low content nutrient environments, so it could be these species as indicators to oligotrophic conditions.
A. aff. robusta is influenced negatively by the water temperature, conductivity, $\mathrm{NH}_{4}$, nitrites, dissolved oxygen concentration and positively by the water level and associated with the presence of Diadesmis confervaceae $(p<0.005)$. This specie presented less optimal conductivity. A. eunotioides presented an optimum value growth in waters little mineralized, oligotrophic and slightly acidic, with a pH equal to 6 and less than $0.2 \mathrm{mg} / \mathrm{L}$ nutrient concentrations.

Cylindrospermopsis raciborskii is a species of planktonic type, however frequently found within the periphytic material, so it was considered in the study. In this research C. raciborskii presented best conditions in low level of the column of water, low transparency, high water temperature, intermediate concentrations of dissolved oxygen with low saturation $(40 \%)$, neutral $\mathrm{pH}$, medium solids concentrations and intermediate nutrients level. [23] founded that environmental variables determinants of C. raciborskii and Lyngbya cf. limnetica were the level of water, the transparency, the concentration of nutrients and solids.

Oedogonium sp. showed optimum conductivity lower than $100 \mu \mathrm{S} / \mathrm{cm}$, like most in diatoms, except Synedragoulardii, Planothidium lanceolatum, Ulnaria ulna and Euastrum sinuosum (chlorophycea). Oedogonium sp. presented intermediate optimal values for all of the variables evaluated, what may be the result of the association of the information of several species, which have not been identified yet due of the absence of reproductive structures and specialized keys. Lyngbya cf. limnetica presented a condition similar to Oedogonium sp., although it presented some optimal values with trend to the left of the figures (low values) as the concentration of OD, oxygen saturation, electrical conductivity, ammonia and nitrites level.

Oscillatoria sp. evidenced intermediate optimal values, however, there is evidence to low oxygen saturation, high water temperature, slightly acid $\mathrm{pH}$ and low concentrations of total dissolved solids.

The diatoms were dominated by pennate form and were selected only two central, Aulacoseira granulata and $A$. granulate var. angustissisima. Both taxa are much related, so the optimal values are very similar. They present an optimal water level of $3 \mathrm{~m}$, a water temperature of $31^{\circ} \mathrm{C}$, oxygen concentrations between 4 and $5 \mathrm{mg} / \mathrm{L}$, saturations below $50 \%$, slightly acidic $\mathrm{pH}$, electrical conductivity of $60 \mu \mathrm{S} / \mathrm{cm}$, with low concentrations of SST and STD, concentrations of $0.15 \mathrm{mg} / \mathrm{L}$ of nitrites and ammonia nitrogen. Among the differences of the optimal values for these two species, the transparency was identified; already $A$. granulata exhibits one optimum value greater than $A$. granulate var. angustissisima and the concentration of nitrates, which the previous trend is reversed. Both species are considered as $\alpha$ mesosaprobic 
and $\beta$ mesosaprobic indicators and environments ranging from oligotrophic to eutrophic environments with low luminosity [18]. A. granulata var. angustissisima was related to ammoniacal nitrogen and $A$. granulata was related to Cylindrospermopsis raciborskii.

Euastrum sinuosum required high nitrogen concentration, especially as ammonia and nitrite, while it presents an optimum value to low concentrations of FSR. This species presented extremely optimal values of the variables frequently, what can impinge on his ability as a bioindicator, since it may be more sensitive to environmental variations. E sinuosum were optimal in surface water, with low transparency, intermediate oxygen concentration, $\mathrm{pH}$ circunneutral, high conductivity (50 to $200 \mu \mathrm{S} / \mathrm{cm}$ ) and low concentration of SST and STD. This species increases its abundance in high waters [24] and inhabits swamp systems with hotter than $29^{\circ} \mathrm{C}$ in mesotrophic environments [25].

Gomphonema parvulum is considered very tolerant to organic pollution in Europe, however, studies in Brazil revealed that indicator of water moderately polluted $(\beta$ mesosaprobic) [20]. In Colombia it has been reported in the Tarapoto lake, Resaca lake, Yahuarcaca III lake (Amazon), Medellin river, Peñol dam (Antioquia); Bogotá river (Cundinamarca); Páramo of Santurbán (Norte de Santander); Paticos swamp (Córdoba), Tota river (Boyacá); Guarino swamp (Magdalena). In the system of flood plains of Ayapel the optimal values for G. parvulum was intermediates for all variables studied, results that are consistent with the values obtained in Brazil.

Navicula cryptocephala presented low optimal values for the water level $(2.8 \mathrm{~m})$, transparency $(0.42 \mathrm{~m})$, electrical conductivity $(50 \mu \mathrm{S} / \mathrm{cm})$, nitrite $(0.1 \mathrm{mg} / \mathrm{L})$, ammoniacal nitrogen $(0.1 \mathrm{mg} / \mathrm{L})$, sulphates $(0.7 \mathrm{mg} / \mathrm{L})$; intermediate values for the temperature of the water $\left(30.8^{\circ} \mathrm{C}\right)$, the concentration of $\mathrm{OD}(4.5 \mathrm{mg} / \mathrm{L})$ with a saturation of the $60 \%$, circumneutral $\mathrm{pH}$, PSR concentration $(0.5$ $\mathrm{mg} / \mathrm{L})$, and high optimal values than other algae for SST $(18 \mathrm{mg} / \mathrm{L})$, TDS $(90 \mathrm{mg} / \mathrm{L})$ and nitrates $(1.8 \mathrm{mg} / \mathrm{L})$. Literature records $\mathrm{pH}$ circunneutral, to withstand desiccation, eurithermic, $\alpha-\beta$ mesosaprobic [18].

Of the genus Eunotia three species were selected: Eunotia minor, Eunotia flexuosa and Eunotia naegueli which are considered as periphytic and acidophilic in the literature [22]. Samples of this genera presented greater abundance with 45 species and was widely identified in spatial gradient of the system according to the slightly acidic $\mathrm{pH}$ conditions presented.

Eunotia minor presented optimal in shallow waters of low transparency, temperature of $30.5^{\circ} \mathrm{C}$, oxygen concentration and intermediate saturation, $\mathrm{pH}$ of 6.3 , conductivity of $50 \mu \mathrm{S} / \mathrm{cm}$, intermediate optimal value of nitrite, nitrate and PSR, high solids concentrations with respect to other algae (15 SST mg/L) and $90 \mathrm{mg} / \mathrm{L}$ of STD and the higher value of nitrates $(1.75 \mathrm{mg} / \mathrm{L})$. E minor moves away from the values of the other two species of the genus and reaches higher abundances.

Eunotia flexuosa is recorded in the literature as indicator of oligotrophic environments, acidic $\mathrm{pH}$ to neutral and may indicate presence of iron [18]. This research found that their optimal values indicate a column of deep water, greater transparency with respect to other algae (Zsd $0.8 \mathrm{~m})$, temperature of the water around $30^{\circ} \mathrm{C}$, intermediate concentrations of OD with low saturation percentage (10\%), $\mathrm{pH} 6.8$, low conductivities (less than $50 \mu \mathrm{S} / \mathrm{cm}$ ), low concentrations of TSS, STD with an optimum value of $73 \mathrm{mg} / \mathrm{L}$, with regard to nutrients presents intermediate optimal values of nitrates $(1.1 \mathrm{mg} / \mathrm{L})$ and PSR $(0.55 \mathrm{mg} / \mathrm{L})$, low concentrations of nitrite $(0.08$ $\mathrm{mg} / \mathrm{L})$ and ammoniacal nitrogen $(0.06 \mathrm{mg} / \mathrm{L})$ and the highest concentrations of sulphates $(3.6 \mathrm{mg} / \mathrm{L})$.

Eunotia naegueli prefers low deep environments with transparency lower, eurithermic, intermediate values of oxygen saturation percentage, slightly acidic $\mathrm{pH}$, low conductivity, concentrations of SST and STD, nitrates, nitrites and PSR and intermediate levels of ammoniacal nitrogen and sulphates. Founded in acidic and oligotrophic environments [18].

Frustulia rhomboides has been registered as an inhabitant of waters of $\mathrm{pH}$ circunneutral, oligotrophic to dystrophic [18]. The information obtained in this research allows to slightly expand in the environmental conditions of distribution of the species. Presented optimal in waters with an intermediate level $(3 \mathrm{~m})$ column values, with low transparency $(0.58 \mathrm{~m})$, water temperature $31^{\circ} \mathrm{C}$, intermediate concentrations of oxygen $(4.3 \mathrm{mg} / \mathrm{L}, 40 \%$ saturation), slightly acid $\mathrm{pH}(6.4)$, low conductivity $(60 \mu \mathrm{S} / \mathrm{cm})$, solids concentrations with respect to other algae (SST 13 $\mathrm{mg} / \mathrm{L}$ and STD $77 \mathrm{mg} / \mathrm{L}$ ), intermediate nitrate concentrations $(1 \mathrm{mg} / \mathrm{L})$, nitrites $(0.12 \mathrm{mg} / \mathrm{L})$, ammoniacal nitrogen $(0.12 \mathrm{mg} / \mathrm{L})$, PSR $(0.47 \mathrm{mg} / \mathrm{L})$ and sulfates $(1.8$ $\mathrm{mg} / \mathrm{L})$.

Diadesmis confervaceae is considered to have a tropical taxa origin that was easily adapted to subtropical conditions of South America and the mild climate of North America, Asia and Europe [26,27]. These latest researchers carried out a comparison of the distribution of the species in different countries, and indicate that it is more frequent in lotic environments. It has been reported as estuarine, $\beta$ mesosaprobic, $\mathrm{pH}$-neutral, supports desiccation, inhabits soft water and it can tolerate pollution [18]. This research found that it presented optimal values in shallow waters in greater depth $(3.8 \mathrm{~m})$, with intermediate transparency $(0.8 \mathrm{~m})$, water temperature $31^{\circ} \mathrm{C}$, intermediate concentrations of oxygen $(4.3 \mathrm{mg} / \mathrm{L}, 38 \%$ saturation), $\mathrm{pH}$ circunneutral $(6,7)$, low conductivity (60 $\mu \mathrm{S} / \mathrm{cm}$ ), solids concentrations (SST $7 \mathrm{mg} / \mathrm{L}$ and STD 48 $\mathrm{mg} / \mathrm{L})$, concentration intermediate in nitrate $(0.7 \mathrm{mg} / \mathrm{L})$, 
and low values of nitrites $(0.06 \mathrm{mg} / \mathrm{L})$, ammoniacal nitrogen $(0.07 \mathrm{mg} / \mathrm{L})$, PSR $(0.34 \mathrm{mg} / \mathrm{L})$ and sulfates $(1.8$ $\mathrm{mg} / \mathrm{L})$.

Encyonema jemtlandicum was described for Colombia by [28] in Tumaradó swamp, Chocó. This is the first record for depression Momposina flood plains. Nearly all the swamps that we sampled the swamp Ayapel and known little ecological information about the species. This research found that their optimal values indicate a water column of intermediate depth $(3 \mathrm{~m})$, with low transparency (Zsd $0.58 \mathrm{~m})$, water temperature around $30.8^{\circ} \mathrm{C}$, intermediate concentrations of OD with low saturation of the same $(4.3 \mathrm{mg} / \mathrm{L}$ and $41 \%), \mathrm{pH}$ of 6.4 , low conductivities (less than $80 \mu \mathrm{S} / \mathrm{cm}$ ), low concentrations of SST $(10 \mathrm{mg} / \mathrm{L})$, STD $(40 \mathrm{mg} / \mathrm{L})$, nutrient concentrations show intermediate values of nitrates $(1 \mathrm{mg} / \mathrm{L})$, nitrites $(0.18 \mathrm{mg} / \mathrm{L})$, ammoniacal nitrogen $(0.18 \mathrm{mg} / \mathrm{L})$, PSR $(0.5 \mathrm{mg} / \mathrm{L})$ and sulphate $(2 \mathrm{mg} / \mathrm{L})$.

Encyonema minutum is considered as $\alpha$-mesosaprobic, circunneutral, euritrophic, $\mathrm{pH}$ circunneutral, indicator of low transparency [18]. This research found that the optimal depth value corresponds to intermediate waters of deep $(2.8 \mathrm{~m})$, with low transparency $(0.6 \mathrm{~m}), 30.8^{\circ} \mathrm{C}$ water temperature, intermediate concentrations oxygen ( 5 $\mathrm{mg} / \mathrm{L}, 40 \%$ saturation), $\mathrm{pH}$ circunneutral (6.4), low conductivity $(80 \mu \mathrm{S} / \mathrm{cm})$, low solids concentrations (SST 11 $\mathrm{mg} / \mathrm{L}$ and STD $50 \mathrm{mg} / \mathrm{L}$ ), intermediate in nitrate concentrations $(0.6 \mathrm{mg} / \mathrm{L})$, nitrites $(0.18 \mathrm{mg} / \mathrm{L})$, ammoniacal nitrogen $(0.17 \mathrm{mg} / \mathrm{L})$, PSR $(0.7 \mathrm{mg} / \mathrm{L})$ and sulfates $(1.8$ $\mathrm{mg} / \mathrm{L})$.

For the genus Fragilaria has been selected two species, Fragilaria capucina and Fragilaria familiaris, this last specie is the first report that is made in Colombia. These two species share optimal values for some variables evaluated, such as the intermediate level of the swamp (3 $\mathrm{m})$, a transparency reduced $(0.6 \mathrm{~m}), 31^{\circ} \mathrm{C}$ water temperature, $5 \mathrm{mg} / \mathrm{L}$ of dissolved oxygen with a saturation between 40 and 60 percent, $\mathrm{pH}$ of 6.6 , conductivity 60 $\mu \mathrm{S} / \mathrm{cm}$, concentration of nitrites $0.18 \mathrm{mg} / \mathrm{L}$, ammoniacal nitrogen $0.18 \mathrm{mg} / \mathrm{L}$ and less than $3 \mathrm{mg} / \mathrm{L}$ of sulfates. Fragilaria familiaris with respect to Fragilaria capucina presented more optimal value for the concentration of SST (12 and $5 \mathrm{mg} / \mathrm{L}$, respectively), STD (50 and 75 $\mathrm{mg} / \mathrm{L}$, respectively), PSR (0.4 and $0.63 \mathrm{mg} / \mathrm{L}$, respectively).

The wide ranges of the physical and chemical variables under the periphytic algae are development due to the large area of the water mirror of flood plains of Ayapel, which reaches a high fluctuation in fact of the flood pulse effect. Presented physical and chemical differences between some swamps that make up the system, condition that is evident in the North-South gradient in which has been found a decrease in the electrical conductivity values and the East-West gradient in which there has been an increase in transparency.

High variation of physical and chemical conditions does not mean that periphytic algae are eurioic since it requires the evaluation of fluctuation in relation with his abundance on the values of each variable. Differences were found between the optimal values for algae and differences in the ranges of variation of each physicochemical variable where the organism occurs. The ability to use algae as bioindicators is associated with their level of tolerance of environmental conditions in which, stenoic algae play a preponderant role.

Data evaluated from research in seven swamps and seven streams in 330 periphyton samples in Ayapel system, presented a wide environmental range, allowing algae species to be considered dominant as bioindicators of water quality and species representative of the assembly, although it is necessary to continue the research for further taxonomic and ecological information of them.

In general, there is very little ecological information existing about these species and is required to continue with this type of research to further debug the distribution of algae in the world and identify the optimal environmental conditions for their development. This claim work is basic to consolidate the application of indices which evaluate the biological quality of water by microalgae.

\section{REFERENCES}

[1] D. E. Bauer, "Ecología del Fitoplancton de Arroyos Pampeanos y su Valor como Indicador de la Calidad del Agua," Ph.D. Thesis, Universidad Nacional de la Plata, 2009.

[2] T. Braak and P. Smilauer, "CANOCO Reference Manual and User's Guide to Canoco for Windows: Software for canonical Community Ordination, Version 4," Ithaca, 1998.

[3] D. Castro-Roa, "Desarrollo de un Índice de Diatomeas Perifíticas para Evaluar el Estado de los Humedales de Bogotá," MSc Thesis, Universidad Nacional de Colombia, 2009.

[4] X. Yang, X. Wu, H. Hao and Z. He, "Mechanisms and Assessment of Water Eutrophication," Journal of Zhejiang University SCIENCE B, Vol. 9, No. 3, 2008, pp. 197 209. http://dx.doi.org/10.1631/jzus.B0710626

[5] B. J. Bellinger, C. Cocquyt and C. M. O'Reilly, "Benthic Diatoms as Indicators of Eutrophication in Tropical Streams," Hydrobiologia, Vol. 1, No. 573, 2006, pp. 7587. http://dx.doi.org/10.1007/s10750-006-0262-5

[6] Y. Montoya-Moreno and N. Aguirre, "Cambios Nictemerales de Variables Físicas y Químicas en la Ciénaga de Paticos, Complejo Cenagoso de Ayapel, Colombia," Revista de Biología Tropical, Vol. 3, No. 57, 2009, pp. 635-646.

[7] Y. Montoya-Moreno, S. Sala, A. Vouilloud and N. Aguirre, "Capartogramma crucicula (Grunow ex Cleve) Ross, 
un Nuevo Registro del Género para Colombia," Revista Universitasscientiarum, Vol. 1, No. 16, 2011, pp. 183-189.

[8] Y. Montoya-Moreno, S. Sala, A. Vouilloud and N. Aguirre, "Diatomeas (Bacillariophyta) Perifíticas del Complejo Cenagoso de Ayapel, Colombia. I," Revista Caldasia, Vol. 2, No. 34, 2012, pp. 457-474.

[9] E. H. Atilano, N. Aguirre and E. M. Gonzalez, "La vida Microscópica en la Ciénaga de Ayapel: El Fitoplancton," 1st Edición, Editorial Universidad De Medellin, Medellín, 2011.

[10] N. Aguirre, O. Caicedo and E. M. Gonzalez, "Las Plantas Acuáticas del Sistema Cenagoso de Ayapel Córdoba, Colombia," 1st Edición, Editorial Universidad De Medellin, Medellín, 2011.

[11] Y. Montoya-Moreno, N. Aguirre and E. M. González, "El Perifiton del Sistema Cenagoso de Ayapel, Córdoba-Colombia," 1st Edición, Editorial Universidad De Medellin, Medellín, 2011.

[12] Y. Montoya-Moreno and N. Aguirre, "Asociación de Algas Perifíticas en Raíces de Macrófitas en una Ciénaga Tropical Colombiana," Revista Hidrobiológica, Vol. 3, No. 18, 2009, pp. 189-198.

[13] Y. Montoya-Moreno and N. Aguirre, "Asociaciones de Algas Perifíticas de Raíces de Eichhorniacrassipesen seis Lagos de Llanura de Inundación Colombianos," Revista Institucional Universidad Tecnológica del Chocó, Vol. 1, No. 30, 2011, pp. 12-24.

[14] D. E. Bauer, N. Gómez and J. Donadelli, "Descriptores Estructurales del Fitoplancton de Arroyos de Llanura como Herramienta de Monitoreo para la Evaluación de la Contaminación Orgánica y la Eutrofización," I Congreso Internacional de Hidrología de llanuras, Azul Buenos Aires Argentina Tomo II, 2010, pp. 369-709.

[15] M. Potapova and D. F. Charles, "Distribution of Benthic Diatoms in U.S. Rivers in Relation to Conductivity and Ionic Composition," Freshwater Biology, Vol. 1, No. 48, 2003, pp. 1311-1328. http://dx.doi.org/10.1046/j.1365-2427.2003.01080.x

[16] R. W. Battarbee, D. F. Charles, S. S. Dixit and I. Renberg, "Diatoms as Indicators of Surface Water Acidity," In: E. F. Stoermer and J. P. Smol, Eds., The Diatoms: Applications for the Environmental and Earth Sciences, Cambridge University Press, Cambridge, 1999, pp. 85-127.

[17] E.Hernández, N. Aguirre, J. Palacio and J. J. Ramírez, "Variación Espacio-Temporal de la Asociación Fitoplanctónica en Diferentes Momentos del Pulso Hidrológico en la Ciénaga de Ayapel (Córdoba), Colombia," Actualidades Biológicas, Vol. 30, No. 88, 2008, pp. 67-81.

[18] R. S. Moro and C. B. Fürstenberger, "Catálogo dos
Principais Parámetros Ecológicos de Diatomáceas Nãomarinhas," Universidade Estadual de Ponta Grossa, Parana, 1997.

[19] P. O. Quevedo, "Ficha Ramsar del Humedal Abras de Mantequilla-Ecuador," 2008.

http://web.ambiente.gob.ec/sites/default/files/users/jloarte fls/Ficha_Abras\%20de\%20Mantequilla\%202009.pdf

[20] E. A. Lobo, M. V. L. Callegaro and E. P. Bender, "Utilização de Algas Diatomáceas Epilíticas como indicadores da Qualidade da ÁguaemRios e Arroios da Região Hidrogáfica do Guaíba, RS, Brasil," Editora da UNISC, Santa Cruz do Sul, 2002.

[21] K. Sabbe, R. L. Vanhoutte, E. A. Bergey, J. F. Biggs, S. Francoeur, D. Hodgson and W. Vyverman, "Six New Actinella (Bacillariophyta) Species from Papua New Guinea, Australia and New Zealand: Further Evidence for Widespread Diatom Endemism in the Australasian Region," European Journal of Phycology, Vol. 1, No. 36, 2001, pp. 321-340.

[22] F. Round, R. M. Crawford and D. G. Mann, "The Diatoms. Biology y Morphology of the Genera," Cambridge University Press, Cambridge, 1990.

[23] E. Hernández, "Estructura de la Agremiación Fitoplanctónica en la Ciénaga de Ayapel en Diferentes Periodos del Pulso Hidrológico," MSc Thesis, University of Antioquia, 2006.

[24] S. Melo, K. Souza, S. Rebelo and M. G. Sophia, "Gêneros Euastrum Ehrenberg ex Ralfs e Micrasterias C. Agardh (Conjugatophyceae-Desmidiaceae) de dois Ambientes Amazônicos de Águaspretas (Manaus, AmazonasBrasil)," Acta Amazonica, Vol. 1, No. 39, 2009, pp. 13-20. http://dx.doi.org/10.1590/S0044-59672009000100002

[25] N. Ngearnpat, F. M. Coesel and Y. Peerapornpisal, "Diversity of Desmids in Three Thai Peat Swamps," Biologia, Vol. 63, No. 6, 2008, pp. 897-902. http://dx.doi.org/10.2478/s11756-008-0140-x

[26] M. Coste and L. Ector, "Diatomées Invasives Exotiques ou Rares en France: Principales Observations Effectuées au Cours des Dernièresdécennies," Systematics and Geography of Plants, Vol. 1, No. 70, 2000, pp. 373-400. http://dx.doi.org/10.2307/3668651

[27] T. L. Carvalho and C. B. dos Santos, "Diadesmis confervacea (Diadesmiaceae-Bacillariophyta): Morfología Externa, Distribuição e Aspectos Ecológicos," Iheringia, Série Botánica, Vol. 1, No. 63, 2008, pp. 171-176.

[28] S. E. Sala, J. J. Ramirez and Y. Plata-Diaz, "Diatoms from Lentic and Lotic Systems in Antioquia, Chocó and Santander Departments in Colombia," Biología Tropical, Vol. 1, No. 56, 2008, pp. 1159-1178. 